\title{
Monetary Policy during the Recession
}

THE DEPTH of the current recession makes it clear ex post that government stabilization policy should have been less contractionary in 1974. In fact, both monetary and fiscal policy were extremely contractionary not only relative to the needs of a declining economy but also relative to policy during the 1972-73 boom. During 1974, the full employment budget surplus rose sharply and monetary expansion slowed markedly. My task in this report is to analyze the monetary part of recent stabilization policies.

A sharp deceleration of money growth (both $\mathrm{M}_{1}$ and $\mathrm{M}_{2}$ ) since mid-1974 is evident in figure $1 .{ }^{1}$ Economists generally agree that money growth in the second half of 1974 was too low, but split over the proposition that money growth in the first half-6.2 percent for $M_{1}$ from December 1973 to June 1974-was about right. ${ }^{2}$ As I argued a year ago, an $\mathrm{M}_{1}$ growth target of about 6 percent was appropriate on the basis of information available in early and mid-1974. ${ }^{3}$ Therefore, I applaud the Federal Reserve for restrain-

Note: I want to thank the Federal Reserve Bank of Boston for research support and especially Ruth Kupfer and Redenta de Leon of the Bank for research assistance and typing. The views expressed, however, are mine and do not necessarily reflect those of the Federal Reserve Bank of Boston.

1. I am inclined to believe that $\mathbf{M}_{2}$ is more closely related to business conditions than $M_{1}$, but have decided to use $M_{1}$ in most of my analysis because the Federal Reserve tends to emphasize it and because the differences in the recent behavior of the two measures are relatively minor.

2. All growth rates in this report are continuously compounded annual rates of growth.

3. William Poole, "Reflections on U.S. Macroeconomic Policy," BPEA (1:1974), pp. 233-46. 
Figure 1. Money Stock and Selected Interest Rates, Monthly, January 1971-March 1975

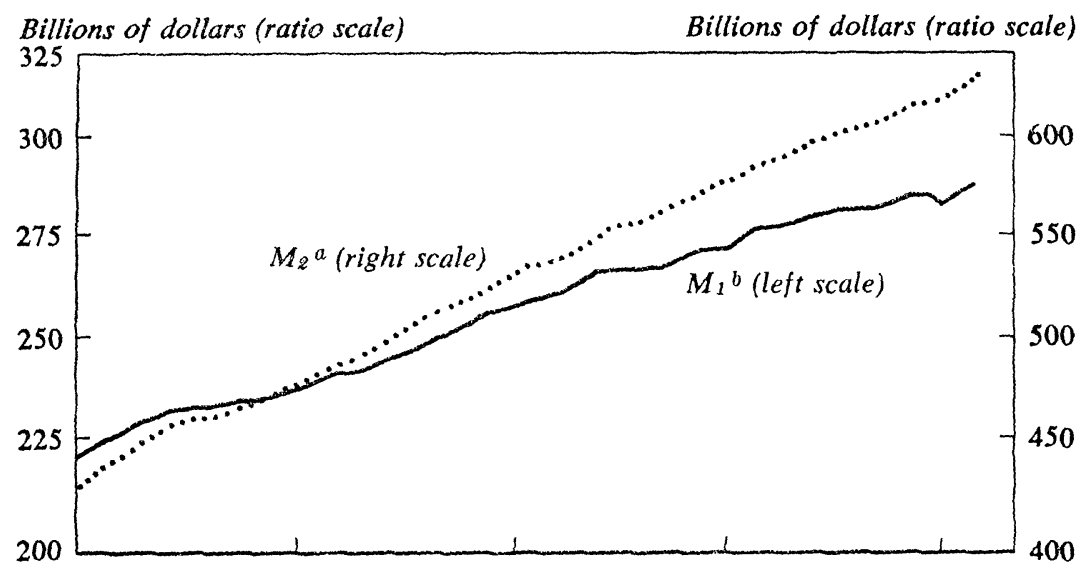

\section{Percent}

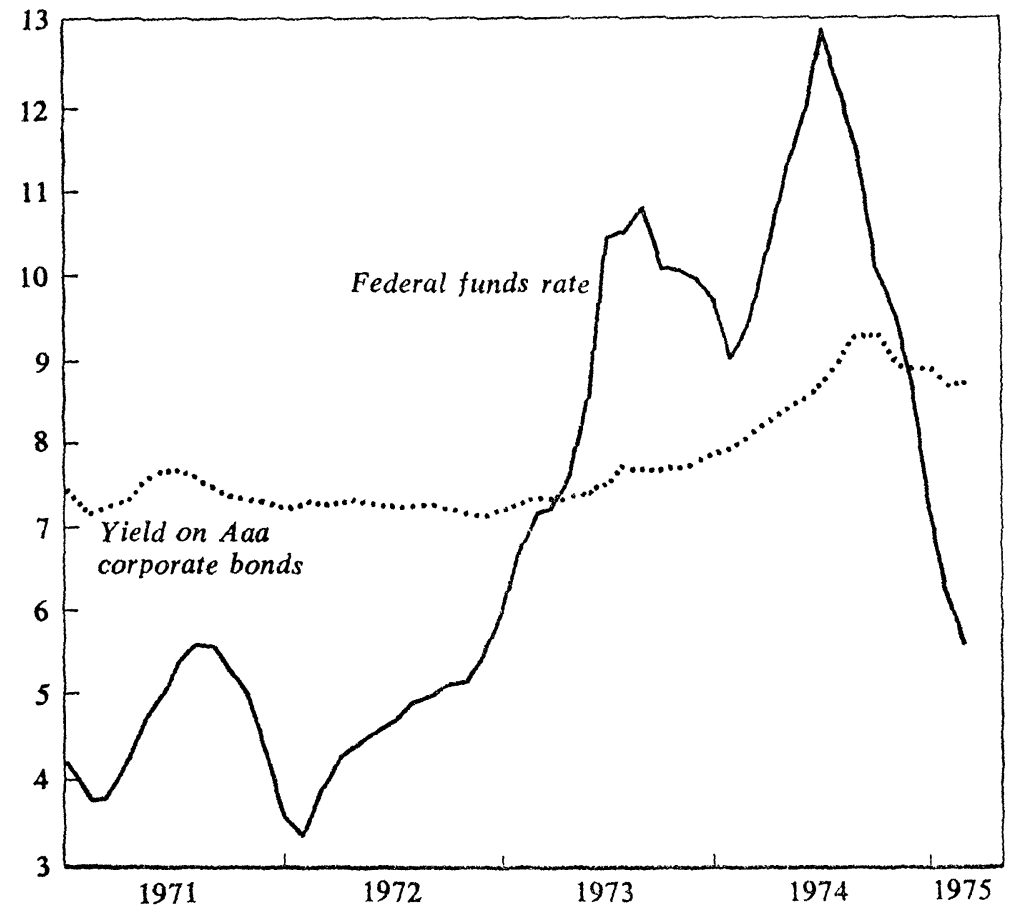

Sources: Federal Reserve Bulletin, various issues.

a. Mi plus time deposits except large certificates of deposit.

b. Currency plus demand deposits at commercial banks. 
ing money growth and permitting interest rates to rise sharply in the first half of 1974.

The next section is devoted to a defense of the proposition that a 6 percent $M_{1}$ growth was appropriate in 1974. There follows an analysis of the Federal Reserve's explanation of monetary policy in the second half of 1974. The report concludes with a few general comments on what the Federal Reserve should do, given recent experience.

\section{Judging the Appropriateness of Monetary Policy}

Policymaking is inherently a problem of decisionmaking under uncertainty; an ex post analysis of policy ought, therefore, to be cast in the same terms. Judging the performance of policymakers requires that something be said about preferences for possible outcomes, especially those related to unemployment and inflation; about the effect of events known to policymakers when decisions are made on the odds of various outcomes; and about the impact on the odds of policy adjustments.

Although opinions differ on the relative costs of unemployment and inflation, I know of no statements by public officials suggesting that the current rapid reduction in inflation has been worth the cost in terms of unemployment. On the contrary, public officials have stressed repeatedly that inflation must be reduced slowly in order to avoid a depression, and that the unavoidable cost was a modest rise in unemployment.

Differences over the role of preferences arise largely because of varying views of how the world works. I assign very little importance to inflation per se but feel that the economic and political dynamics of inflation combine to rule out any significant chance of simply stabilizing the rate of inflation at 1973 or 1974 levels. Further acceleration of inflation very likely would have generated vastly increased odds of deeper recession in the future.

I basically agree, then, with Milton Friedman's argument that the real choice is not between inflation and unemployment, but between unemployment now and unemployment later. ${ }^{4}$ This is an empirical statement-correct or incorrect-about the way the world works and not about preferences. Nevertheless, the tradeoff between unemployment now and unem-

4. Milton Friedman, "The Role of Monetary Policy," American Economic Review, vol. 58 (March 1968), pp. 1-17 (especially 7-11). 
ployment later applies only within a certain range. After a point, more unemployment now clearly brings more unemployment later, again for a mixture of economic and political reasons. When firms go bankrupt and are dismantled or fall far behind in their capital spending, an irreversible loss occurs, and production and employment cannot be returned easily to full employment levels. In addition, some government actions taken in response to unemployment, as well as in response to inflation, reduce economic efficiency and interfere with the return to full employment.

I also agree with the Modigliani-Papademos argument that the desirable path for the economy is one involving the fastest possible recovery consistent with maintaining low odds of overshooting full employment and reaccelerating inflation. ${ }^{5}$ I differ with Modigliani and Papademos not over goals but over the odds of achieving any given target path for the economy. This point will be discussed further in my comments on current policy, but it is central to my analysis of Federal Reserve policy in 1974.

\section{THE EVIDENCE OF 1974}

Whatever lessons evolve from the sharp rise in unemployment in late 1974 and early 1975, an analysis of monetary policy in 1974 should be limited to the evidence available at the time the policy decisions were made. The consensus forecast in early 1974 was for a flat economy. Pessimists argued that a couple of quarters of declining real gross national product were likely and optimists thought a recession would be avoided. No one foresaw either a deep recession or a boom. ${ }^{6}$

By June the forecasts became, if anything, a bit more optimistic. The disruptive oil embargo had been lifted, the unemployment rate was the same as in January, and the index of industrial production actually had risen a bit since April.

From what is known now, the business cycle peak may be tentatively placed at November 1973. However, after a significant decline in the early months of 1974, the economy remained basically on a plateau until autumn. As the year continued, the consensus forecast was revised downward, but

5. See their paper in this issue.

6. It is fair to say that a year ago many economists were concerned over the possibility that maintaining a 6 percent trend of money growth would lead to a prolonged period of economic slack, with unemployment remaining above 6 percent, and perhaps rising slowly, for several years. No one I know, however, assigned any significant probability to a 1975 unemployment rate of the current magnitude. 
this plateau led most forecasters to believe that any further contraction would be relatively mild. Indeed, even as late as fall, many forecasters anticipated only a moderate recession. The "Typical Quarterly Forecast for 1975"- the median quarterly forecast among twenty-three surveyed by the Federal Reserve Bank of Richmond-had a quarterly pattern of unemployment for 1975 of 6.8, 7.0, 7.2, and 7.3 percent, respectively. ${ }^{7}$ Since seventeen of the twenty-three forecasts are dated December 1, 1974, or later, it is clear that the magnitude of impending unemployment was completely unforeseen by the professional forecasters, or at least not foreseen with enough confidence to be included in the published forecasts.

Critics of monetary policy in the first half of 1974 point to three reasons why unusually rapid money growth would have been appropriate: exogenous shocks in the form of the oil embargo, and short harvests in 1973; the sideways movement of the economy; and the rapid escalation of interest rates.

Shocks. Those who emphasize the importance of the recent shocks from farm and fuel products have not, as far as I know, referred to similar past episodes in support of their position favoring a more expansionary monetary policy. The Korean War experience presents some intriguing parallels, at least on the surface. Raw material and farm prices surged sharply upward following the outbreak of the war, transferring income to foreign producers of primary products. However, most of this income transfer was probably saved in the short run, and the U.S. balance on goods and services (excluding military) declined by $\$ 4.3$ billion between 1949 and 1950. Even the high-employment federal budget surplus rose until late in 1950. But the Korean War shock did not produce a recession and the 1950 acceleration of money growth has to be viewed, in retrospect, with regret rather than pleasure.

My point is not to offer the Korean War experience as a counter-example, but rather to argue that the case for a more expansionary policy in 1974 ought to rest on more than simply feeding an assumed surge in the aggregate price level into a standard macro model. The underlying micro behavioral equations reflect the holding of inventories and precautionary balances by individual economic units precisely in order to cushion the effects of unforeseen disturbances. The advocates of a policy response to the oil shock ought, therefore, to display some evidence that outsize micro

7. Federal Reserve Bank of Richmond, Business Forecasts, 1975 (February 1975), p. 5. 
shocks in the past have had the macro effects postulated. Historically, there has been a tendency for economic policy to overreact to external events. Given the record, it seems best to maintain neutral policy settings in the absence of compelling evidence that a "clear and present danger" requires a policy response.

Sideways economy. The basically sideways movement of the economy in the spring and summer of 1974 was an obvious danger sign. The pattern was not dissimilar, however, to that characterizing most of 1962 and late 1966 through early 1967-periods that terminated in renewed expansion rather than contraction. No solid criteria have been developed to distinguish the economic "pause that refreshes" from one that forebodes real trouble.

Interest escalation. The significance of the sharp escalation of short-term interest rates in early 1974 cannot be ignored even though the rise was actually smaller than that in the first half of 1973. Rising rates in 1973, as in most other periods of business expansion, were appropriate in retrospect, and the key question is whether sufficient information was available to distinguish the 1974 case from the others. The economy was obviously somewhat weak in 1974, but given the lags in the effects of a changed rate of monetary growth, this weakness is relevant only insofar as it affects the economic forecast for four to six quarters ahead. That forecast held that the economy would level off, or fall a bit, and then resume its expansion.

Interest rates rose far more rapidly in the first half of 1974 than would have been anticipated at the beginning of the year given actual money growth. The proper response of monetary policy to such an unexpected change in interest rates depends crucially on whether the change is the result of a financial or a real disturbance. I have seen no evidence suggesting that it stemmed from a financial disturbance.

In U.S. business cycle experience, steady or accelerating money growth and rising short-term interest rates are generally associated with expanding economic activity; similarly, decelerating money growth and falling interest rates are standard recession phenomena. Exceptions are few. Given these patterns, the evidence would have to be very strong to prove that the proper policy response to interest rate pressures, either up or down, is a sustained acceleration or deceleration of money growth. Since the goal of monetary policy in early 1974 was to permit a little slack to develop in the economy to reduce the risk of a further acceleration in inflation, the Federal Reserve appropriately maintained a rate of money growth roughly equal to the average of the preceding several years. 
However, monetary policy in the second half of 1974 was ill-advised for exactly the same reasons. Declining money growth in the face of downward interest rate pressures should have been recognized as characteristic of recession. Even ignoring accompanying interest rate movements, the case against permitting sharp monetary deceleration is overwhelming. Over the entire period since mid-1907 for which monthly data on the money stock are available, every recession was accompanied by a significant deceleration of money growth and every significant deceleration of money growth was accompanied by recession. ${ }^{8}$

My position may be summarized as follows: if money growth is measured over six-month spans and compared with the average rate of growth over the preceding two or three years, most accelerations or decelerations of 2 percentage points or more will be found to have been undesirable under almost any preference function. Judgments vary as to the importance of these monetary accelerations and decelerations in generating the business cycle. Nonetheless, if large monetary accelerations and decelerations are typically regretted after the fact, then-even if monetary instability is not very important-there is no point in having monetary policy push in the wrong direction. The Federal Reserve was playing the odds correctly in the first half of 1974 by holding money growth to about 6 percent. But by permitting the sharp monetary deceleration in the second half of 1974, it was playing with adverse odds of at least 8 to 1 calculated from 1952-73 experience. ${ }^{9}$ The adverse odds were very much higher if the extensive prewar recession experience is also counted. Moreover, these findings were available to the Federal Reserve in the second half of 1974, and should have guided policy decisions.

There are only two possible defenses for the sharp monetary deceleration in late 1974. It might be argued, first, that persuasive evidence was available

8. See William Poole, "The Relationship of Monetary Decelerations to Business Cycle Peaks: Another Look at the Evidence," Journal of Finance, vol. 30 (forthcoming). In this paper the meaning of "significant deceleration" is defined carefully.

9. These odds were calculated by measuring money growth over six-month periodsDecember-June, and June-December-and then examining all cases between 1952 and 1973 in which money growth was more than 2 percentage points below the average for the preceding three years. The nine periods of sharply decelerated money growth were both halves of 1953, both halves of 1957, the second half of 1959 , the first half of 1960 , the second halves of 1966, 1969, and 1971. Given the actual performance of the economy in the months following these decelerations, I regard seven of the nine decelerations as clearly inappropriate, the 1971 deceleration as probably inappropriate, and the 1966 deceleration as possibly appropriate. 
suggesting that the significance of the money stock had changed; or, second, that the Federal Reserve is unable to control the money stock and therefore is not responsible for the sharp monetary deceleration. These two arguments will now be discussed in turn.

\section{Federal Reserve Explanations}

The Federal Reserve's position has been expressed clearly in two recent statements in response to proposed congressional legislation concerning the conduct of monetary policy. ${ }^{10}$

A careful reading of these two statements raises questions about the internal consistency of the Board's position. On the one hand, the Board seems to accept the argument presented in the previous section:

We appreciate the fact that an expanding economy requires an expanding supply of money, that any protracted shrinkage of the money supply may well lead to shrinkage of economic activity, and that attempts to encourage growth in money and credit will lead to a decline of short-term interest rates when economic activity is weak.

We are well aware that an expanding economy needs an expanding supply of money and credit and that any protracted shrinkage of the money stock could lead to or exacerbate a shrinkage of economic activity. ${ }^{11}$

On the other hand, the Federal Reserve seems to argue that lower $M_{1}$ growth in the second half of 1974 was acceptable because the significance

10. In regard to H.R. 212, "Statement by Arthur F. Burns, Chairman, Board of Governors of the Federal Reserve System, before the Subcommittee on Domestic Monetary Policy of the Committee on Banking, Currency and Housing, U.S. House of Representatives, February 6, 1975," Federal Reserve Bulletin, vol. 61 (February 1975), pp. 62-68 (hereafter referred to as "FRB Statement 1"); and in regard to Senate Concurrent Resolution 18, "Statement by Arthur F. Burns, Chairman, Board of Governors of the Federal Reserve System, before the Committee on Banking, Housing and Urban Affairs, U.S. Senate, February 25, 1975," Federal Reserve Bulletin, vol. 61 (March 1975), pp. 150-55 (hereafter referred to as "FRB Statement 2").

11. FRB Statement 1, p. 63, and Statement 2, p. 153. These two statements, however, are less precise than they first appear since "shrinkage" of the money stock, interpreted literally, involves an absolute decline and "protracted" involves a period of unspecified length. Given the context of recent monetary analysis and the frequent reference to monetary growth rates in the two statements, it is reasonable to interpret "shrinkage" in terms of a decline in the growth rate of money. There is no clear interpretation of the word "protracted," but the Federal Reserve has frequently argued that fluctuations in money growth are unimportant unless they last for a year or more. 
of $\mathrm{M}_{1}$ has been changing. This argument, however, is inconsistent with the Board's argument that it has attempted to achieve faster growth in the monetary and credit aggregates. Finally, the Federal Reserve has argued that it cannot control the money stock very precisely anyway.

\section{CHANGES IN THE SIGNIFICANCE OF $M_{1}$}

The argument that the significance of $\mathrm{M}_{1}$ has changed appears prominently in both statements:

As a rule consumers and businesses no longer hold all, or even most, of their spendable funds as currency or demand deposits. More and more corporate treasurers have learned how to get along with a minimum of demand deposits; a large part of their transactions and precautionary balances are nowadays placed in interest-bearing assets-negotiable certificates of deposit, Treasury bills, commercial paper, short-term municipal securities, and other forms. Consumers, too, have learned to keep excess funds in savings deposits at commercial banks, shares in savings and loan associations, certificates of deposit, Treasury bills, and other liquid instruments, and they shift their liquid resources among these assets. The result is that no single concept of money any longer measures adequately the spendable funds that are held by the public.

For example, the narrowly defined money stock rose by $4 \frac{1}{2}$ per cent during 1974. But this concept of the money supply has lost much of its earlier significance. ${ }^{12}$

The possibility of changing economic relationships is a constant source of concern to policymakers and advisers, properly reflected in a continuous search for evidence of change and a willingness to shade policy targets depending on the strength of the evidence.

The evidence for a changing significance for $M_{1}$ in 1974 is not strong. Starting with the April 1975 issue of the Federal Reserve Bulletin, monthly data for five different monetary aggregates are published. The growth rates for these aggregates in 1973 and 1974 are reported in table 1, and all show decelerations of roughly similar magnitude. If a significant shift out of $\mathbf{M}_{1}$ had taken place in 1974, divergent movements in $\mathrm{M}_{1}$ and, say, $\mathrm{M}_{2}$ would have been expected. Given the uncertainties, an appropriate policy response might have been to aim for some deceleration in $\mathrm{M}_{1}$ and some acceleration in $\mathrm{M}_{2}$, but in fact the decelerations in the aggregates, however defined, were about the same.

12. FRB Statement 2, pp. 153-54. 
Table 1. Growth Rates of Selected U.S. Monetary Aggregates, 1972-74

Annual rate in percent, continuously compounded

\begin{tabular}{cccc}
\hline & \multicolumn{3}{c}{ Growth rate } \\
\cline { 2 - 4 } $\begin{array}{c}\text { Monetary } \\
\text { aggregate }^{\mathrm{a}}\end{array}$ & $\begin{array}{c}\text { December 1972- } \\
\text { December 1973 }\end{array}$ & $\begin{array}{c}\text { December 1973- } \\
\text { December 1974 }\end{array}$ & $\begin{array}{c}\text { Change } \\
\text { percentage } \\
\text { points) }\end{array}$ \\
\hline $\mathrm{M}_{1}$ & 6.0 & 4.6 & -1.4 \\
$\mathrm{M}_{2}$ & 8.5 & 7.0 & -1.5 \\
$\mathrm{M}_{3}$ & 8.5 & 6.5 & -2.0 \\
$\mathrm{M}_{4}$ & 11.0 & 10.1 & -0.9 \\
$\mathrm{M}_{5}$ & 10.1 & 8.6 & -1.5 \\
\hline
\end{tabular}

Source: Calculated from dollar figures in the table, "Measures of the Money Stock," Federal Reserve Bulletin, vol. 61 (June 1975).

a. The measures are defined as follows:

$\mathrm{M}_{1}$ : Averages of daily figures of (1) demand deposits of commercial banks other than domestic interbank and U.S. government deposits, less cash items in process of collection and Federal Reserve float; (2) foreign demand balances at Federal Reserve banks; and (3) currency outside the Treasury, Federal Reserve Banks, and vaults of commercial banks.

$\mathbf{M}_{2}$ : Average of daily figures for $\mathbf{M}_{1}$ plus savings deposits, time deposits open account, and time certificates other than negotiable certificates of deposit of $\$ 100,000$ of large weekly reporting banks.

$M_{3}: M_{2}$ plus deposits at mutual savings banks, savings and loan shares, and credit union shares (nonbank thrift).

$\mathbf{M}_{4}$ : $\mathbf{M}_{2}$ plus large negotiable certificates of deposit.

$M_{5}:$ Ms plus large negotiable certificates of deposit.

The FRB statement above mentions even broader aggregates of liquid assets-including Treasury bills, commercial paper, and so forth-but monthly data for these broader aggregates are not published. More comprehensive data are available in the flow-of-funds accounts, but these are not published on a timely basis and are of little value in month-by-month policymaking.

The rate of turnover in demand deposits might also suggest a changed significance for $\mathrm{M}_{1}$. The reasons for changes in turnover-the ratio of demand deposit debits to demand deposits-are not well understood; the average annual rate of increase of deposit turnover between December 1964 and December 1971 was 8.8 percent while the rates of increase in 1972, 1973, and 1974 (December to December) were 8.0, 19.5, and 15.0 percent, respectively. If these numbers mean anything, the Federal Reserve should have forced a sharp deceleration of $\mathrm{M}_{1}$ growth in 1973 and a mild acceleration in 1974.

Obviously, new theories and new data could overturn the empirical regularity that sharp decelerations of money growth are associated with recessions, but they also could confirm the empirical regularity. In the absence of compelling evidence to the contrary, the safest course is to assume that $\mathrm{M}_{1}$ has the same significance as in the past. 


\section{IMPOSSIBILITY OF CLOSELY CONTROLLING $\mathrm{M}_{1}$}

For some time the Federal Reserve has argued that tight control of the monetary aggregates is technically impossible:

First, H.R. 212 assumes that the Federal Reserve can control the rate of growth of demand deposits plus currency in public circulation over periods as short as 3 months. This we are unable to do. All that we can control over such brief periods is the growth of member bank reserves; but a given rate of growth of reserves may be accompanied by any of a wide range of growth rates of the narrowly defined money supply. ${ }^{13}$

Clearly, the short-run relationship between the change in reserves and the change in the money stock has substantial variability. However, the Federal Reserve should be able to offset much of this variability. From reports submitted by member banks, the Federal Reserve has a complete enumeration of daily member bank deposits within eight days of the end of each statement week, and partial data are available even sooner. Estimates of nonmember bank data and of currency in the hands of the public are required to complete the money stock estimates. These estimates are subject to errors and uncertainties, but the differences between preliminary and final estimates are minor compared to the shortfall in money growth in the second half of 1974. Since reasonably accurate data on the money stock are available on a timely basis, the Federal Reserve has ample opportunity to react to undesired trends in money growth by changing the growth in bank reserves. Most of the short-run variability in the ratio of money growth to reserve growth should be in the denominator of the ratio-reserves-rather than in the numerator-the money stock.

In any case, the slowdown in money growth during 1974 came not from a drop in the ratio of money to reserves but rather from a deceleration in reserve growth. Member bank reserves grew at a continuously compounded rate of 11.1 percent over the twelve months ending December 1973 but at a 4.9 percent rate over the twelve months ending December 1974. Moreover, reserves grew at a rate of only 0.9 percent in the six-month period ending December 1974 , in contrast to an 8.8 percent rate in the previous six-month period.

The Federal Reserve has argued that its attempts to expand bank reserves may be ineffective in some circumstances:

The Federal Reserve can supply the banking system with reserves through open market operations or through reserve requirement changes; but if banks

13. FRB Statement 1, p. 64. 
choose to repay debt or rebuild their liquidity, these actions will have little impact on the public's money supply. ${ }^{14}$

This position raises questions about two effects of open market operations: the first, on member bank borrowing from the Federal Reserve; and the second, on member bank holdings of excess reserves.

Member bank borrowing at the discount window fluctuated substantially in 1974, rising from a December 1973 average of $\$ 1.3$ billion to a peak of $\$ 3.4$ billion in August 1974, and then dropping to $\$ 0.7$ billion in December. The amount of outstanding borrowing is, of course, on the books of the Federal Reserve, and hence known continuously. While it is true that under the current system of lagged reserve requirements-a system that fixes in advance the dollar amount of required reserves in any particular weekincreases in borrowings cannot be immediately offset by open market sales, declines in borrowings can nonetheless be offset by open market purchases.

The Federal Reserve has argued: "Of late, open market policy has been reinforced by other monetary instruments. The discount rate was reduced on three occasions-in December, January, and again early this month [February]-from 8 per cent to $63 / 4$ per cent." 15 But the incentive for banks to use the discount window has declined substantially as open market interest rates have fallen to a much greater extent. The federal funds rate averaged 12.01 percent in August 1974, 4 percentage points above the discount rate. Four months later, in December, the funds rate averaged 8.53 percent, or about $3 / 4$ of 1 percentage point above the discount rate. By March 1975 the federal funds rate averaged 5.54 percent, about 11/4 percentage points below the discount rate of $63 / 4$ percent. The sharp decline in member bank borrowings was largely predictable due to this sharp change in the spread between the discount rate and open market rate. ${ }^{16}$

For a given quantity of total reserves, attempts by member banks to rebuild liquidity through a restructuring of their assets can contract deposits only if the banks hold excess reserves. Member bank excess reserves were \$262 million in December 1973, and \$131 million and \$339 million, respectively, in June and December of 1974. These small swings in excess reserves

14. FRB Statement 2, p. 152.

15. FRB Statement 2, p. 151.

16. This discussion is not meant to imply that the discount rate should have remained 4 percentage points below the federal funds rate. The discount rate is best held continuously above the funds rate; but having failed to maintain such a relationship in mid-1974, the Federal Reserve should have anticipated the sharp decline in borrowing as market rates dropped more rapidly than the discount rate. 
are clearly of trivial consequence given total reserves that exceed $\$ 35$ billion.

The Federal Reserve has also argued that there is a link between bank loan demand and money creation:

The Federal Reserve can have a marked influence on short-term interest rates and may also have some indirect influence on other terms of credit. But it cannot force businesses or consumers to borrow from their banks and thus to expand the volume of bank loans. The Federal Reserve cannot force people to hold money in the form of demand deposits when they prefer to hold their transactions or precautionary balances in income-earning assets. ${ }^{17}$

If the Federal Reserve had maintained a higher rate of growth of total member bank reserves, and if member banks had continued their longstanding practice of holding only minimal amounts of excess reserves (which earn no interest), then deposit growth would have been sustained. Even if bank loan demand had remained sluggish, banks would have purchased securities and thus added to deposits until their liabilities subject to reserve requirements-predominantly demand and time deposits-had expanded sufficiently to absorb all of the reserves supplied by the Federal Reserve.

In terms of the composition of assets, banks have not become more liquid. Of total loans and investments for all commercial banks, loans were 71.5 percent at the end of June 1974, and 72.5 percent at the end of December. Federal Reserve policies did not permit banks to increase their holdings of liquid money-market instruments. That banks have attempted, unsuccessfully, to improve their liquidity is suggested by the large increase in the spread between the prime rate and the commercial paper rate. In June and July of 1974 the prime rate was only a little above the commercial paper rate; but in December the spread was about 1.5 percentage points, and it had increased somewhat further by March 1975.

If the Federal Reserve had maintained the 1973 rate of growth of bank reserves in 1974, then interest rates on open market securities would have declined sufficiently to induce the nonbank public to hold the larger quantity of demand and time deposits. While the Federal Reserve cannot directly control the mix of demand and time deposits, it certainly can ensure that sharply reduced rates of growth do not occur in both $\mathrm{M}_{1}$ and $\mathrm{M}_{2}$.

Finally, the Federal Reserve has pointed to reductions in reserve requirements as additional evidence of a more expansionary policy: "Reductions

17. FRB Statement 2, p. 152. 
in member bank reserve requirements were also ordered-in September, November, and January, releasing a total of nearly $\$ 21 / 2$ billion of reserves to the banking system." 18 But these reductions in reserve requirements were largely offset by open market operations that drained a roughly equivalent amount of reserves from member banks. Total reserves, measured on a basis incorporating seasonal adjustments but without adjustments for changes in reserve requirements, fell from $\$ 36.86$ billion in October 1974 to $\$ 34.86$ billion in March 1975.

\section{Concluding Comments}

The explanation for the low rate of money growth in the second half of 1974 is, I feel, quite simple. It results partly from the operating procedure of the Federal Reserve that pegs the federal funds rate in a narrow band day by day, and, given this procedure, partly from an unwillingness to reduce the peg on the funds rate rapidly enough to maintain money growth. ${ }^{19}$

An enormous scale of open market operations is employed to maintain the federal funds rate in the narrow band specified by the Federal Open Market Committee. For example, in December 1974, the net change in Federal Reserve holdings of U.S. government securities, federal agency obligations, and bankers' acceptances was $\$ 393$ million. However, during the month of December, gross outright purchases of U.S. government securities and federal agency obligations were $\$ 1.614$ billion and gross sales and redemptions of these items were $\$ 432$ million, for a net of $\$ 1.182$ billion. On top of these transactions were $\$ 11.470$ billion of gross purchases, and $\$ 11.895$ billion of gross sales, of government securities under repurchase agreements, for net sales of $\$ 425$ million. Extensive operations in matched sale-purchase transactions ("reverse repurchase agreements") involved

18. FRB Statement 2, p. 151.

19. The Federal Reserve's day-by-day operating procedure is basically the same as that used in the late 1960s before the adoption of targets for monetary aggregates. The continued use of a procedure clearly not well designed for the purpose of achieving such targets reflects the inertia inherent in any organization and the Federal Reserve's continuing concern with day-to-day stabilization of interest rates. This operating procedure has been described in "Numerical Specifications of Financial Variables and Their Role in Monetary Policy," Federal Reserve Bulletin, vol. 60 (May 1974), pp. 333-37; and William Poole, "The Making of Monetary Policy: Description and Analysis," New England Economic Review (March/April 1975), pp. 21-30. 
gross sales of $\$ 8.855$ billion and gross purchases of $\$ 7.962$ billion, for net sales of $\$ 893$ million. Thus, total gross purchases for December were $\$ 21.046$ billion, and total gross sales and redemptions were $\$ 21.182$ billion. Finally, transactions reported only on a net basis-repurchase agreements of agency obligations, outright purchases and repurchase agreements of bankers' acceptances-netted $\$ 531$ million. ${ }^{20}$

Open market activity of this magnitude is unnecessary to control member bank reserves. Although Federal Reserve statements sometimes imply that open market operations are adjusted so that the federal funds rate is expected to fall in a certain range, Federal Reserve policy more accurately involves whatever open market operations are required to peg the funds rate in a narrow day-by-day range. The peg is then adjusted occasionally depending on the FOMC's view of desired money growth and the importance of that objective relative to the interest rate objective:

Moreover, the condition of credit markets also weighs heavily in decisions on monetary policy. There is a school of thought that holds that the Federal Reserve need pay no attention to interest rates, that the only thing that matters is how this or that monetary aggregate is behaving. We at the Federal Reserve cannot afford the luxury of any such mechanical rule. ${ }^{21}$

While policymakers should consider all available information, the policy of pegging the federal funds rate day by day, and changing the peg in response to observed money growth, is no less mechanical than the policy of maintaining steady money growth, and much more damaging because it leads to procylical behavior of the money stock. To call one policy or another "mechanical" begs the issue. Policy must be based on empirical regularities, and whenever relationships clearly are changing it is appropriate to adjust policy. The Federal Reserve, however, has offered no evidence that economic relationships have been changing in a direction that justifies the policies followed in the second half of 1974.

These operating procedures provide one more reason for unhappiness with Federal Reserve policy in the first half of 1974-concern that it would

20. The December 1974 figures discussed in the text may be found in Federal Reserve Bulletin, vol. 61 (March 1975), p. A11.

I have not conducted a systematic examination of the typical gross monthly scale of open market operations relative to the net changes. December 1974, however, does not appear to be atypical. The largest net change for any month in 1974 was August, with a net increase of $\$ 3.322$ billion. In that month, gross purchases under regular and reverse repurchase agreements alone amounted to $\$ 13.383$ billion.

21. FRB Statement 1, p. 64. 
not permit interest rates to drop rapidly enough, once they were pushed up, to maintain money growth at a reasonable rate. Indeed, the Federal Reserve seems to accept this argument in the other direction as it applies currently:

If, for example, we presently encourage a sharp decline of interest rates on top of the decline that has already occurred in recent months, we would run the risk of seeing short-term interest rates move back up while the economy is still receding. There is, moreover, a very real possibility that, as a result of such a policy, a monetary base would be established for a new wave of inflation in the future and that market expectations of such a development would lead rather promptly to a rise of long-term interest rates. ${ }^{22}$

The fear is valid under current Federal Reserve operating procedures. Under an FOMC procedure that permits only slow and "orderly" changes in the federal funds rate, money growth is likely continually to be off target as the adjustments in the funds rate lag behind market pressures.

But why should the Federal Reserve maintain these procedures? No possible gain warrants the costs imposed from extensive day-by-day open market operations to limit fluctuations in the federal funds rate. Moreover, this policy has obviously failed to stabilize the federal funds rate over spans of six to twelve months. Excessive money growth over several quarters at a time-as in 1967-68 and 1972-73-may temporarily cushion upward pressures on interest rates, but only at the cost of exacerbating inflationary pressures and raising the ultimate interest rate peak. Conversely, abnormally low money growth - as in 1957 and late 1974-may temporarily cushion declines in interest rates, but only at the cost of deepening recessions.

The Federal Reserve should promptly reform its operating procedures. The FOMC should direct the Open Market Manager to achieve the rate of growth in nonborrowed reserves necessary to attain the target rate of money growth, and the federal funds rate should be permitted to fluctuate without limit. The goal should be to return promptly to a 6 percent money growth path, projected from June 1974, in order to erase the mistake of the second half of 1974. As of April 1975, the shortfall below the path amounted to $\$ 7.3$ billion, or 2.5 percent. Once back on that 6 percent path, the money stock should be kept there until the economy has recovered sufficiently to warrant a lower trend rate of money growth consistent with long-run price stability.

22. FRB Statement 1, p. 64. 
Many economists share the Modigliani-Papademos position that a much more expansionary monetary policy is needed. I would agree if I were confident of model estimates of the policies required to engineer their projected employment path. But I suspect that the differences in the simulated outcomes under their policy proposal and my policy proposal are, from past experience, far smaller than the model errors themselves. The safest course is to avoid major departures from policy settings that, if maintained five years at a time, would be expected to be in the right range. The recent forecasting fiascos make it abundantly clear that knowledge is inadequate to make significant departures from a trend path of money growth a good bet.

By trying to do too much, policymakers have put themselves into a vicious "stop-go" cycle with ever-widening oscillations. Each period of monetary expansion has been higher than the previous one-considering the 1965, 1967-68, and the 1972-73 expansions. Each of the inflations since 1965 has been worse than the previous one. And each setback in real activity since 1965 has been deeper than its predecessor-in the sequence 1967, 1969-70, 1974-75. This pattern must be broken, and the only method in which I have any confidence is that of stabilizing money growth and permitting the economy to settle down to a stable policy environment.

The discussion of this report is combined with that of the ModiglianiPapademos report which follows. 